
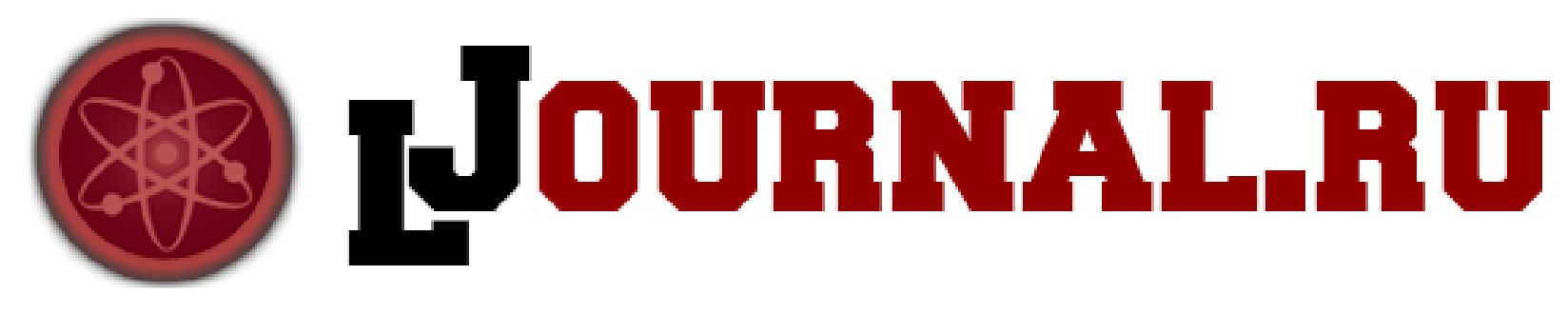

Скворцова А.Ф.

Краснознаменский филиал МЮИ

Россия, Краснознаменск

doi: 10.18411/lj2016-2-23

\title{
И даже в эпоху перемен человек должен оставаться... человеком
}

В начале 90-х годов XX века одними из первых сполна, с лихвой ощутили на себе реорганизации, связанные со сменой формы государства, с коренными преобразованиями во всех сферах общества выпускники военных учебных заведений - пограничники. Они - совершенно разные по внешнему виду, взглядам, привычкам, физической и интеллектуальной подготовке. Что помогло им с честью пройти этот тяжёлый путь в истории нашего государства? Они не поменяли свои шинели на иные ремёсла, не покинули Родину в поисках удачной жизни, не искали за счёт сослуживцев безопасного места службы. Возможно на них повлияли выработанные годами учёбы военная дисциплина, ответственность за слова и дела, верность выбранной профессии и «офицерская честь», которое случается подтверждать порой, даже ценою в жизнь.

Окинем взглядом события двадцати трёхлетней давности на таджикскоафганской границе и вспомним имя Михаила Майбороды. Мы набрались смелости и написали письмо его родителям - Виктору Матвеевичу и Нине Ивановне. И выдержки из письма будем использовать в статье.

Михаил Майборода родился в 1968 году в городе Алма-Ата Казахской ССР. Каким Миша был в детстве? Хорошим честным мальчиком, самым лучшим. Был правильным, понятливым, любознательным. В 4 года уже бегло чи- 
тал, особенно нравились книги про войну, про пограничников. Какая у Миши была успеваемость в школе по предметам? Миша очень любил учиться, у него не было нелюбимых предметов. В школу приходил раньше времени. Никогда не опаздывал. Был почти отличником: в аттестате после 10 класса у него было всего 3 четвёрки (по алгебре, по геометрии и по черчению).

27 октября 1986 года был призван Московским районным военным комиссариатом г. Алма-Аты. Что побудило Мишу связать свою жизнь с судьбой пограничника и поступить в военное училище? Очень много читал про пограничников, да ещё и нравились политработники - тогда они были самыми честными и самыми хорошими. Кинофильмы про бандитов и воров совершенно не воспринимал. Миша поступил даже несмотря на то, что зрение на одном глазу было неважнецкое, но стрелял всё равно отлично.

В июне 1991 года М. В. Майборода окончил высшее военно-пограничное училище КГБ СССР, получив офицерское звание - лейтенант [1]. Возможно, людям сведущим, уже ощущалось дуновение ветра перемен: 1985-1988 гг. стали первым этапом тотальных изменений; парад суверенитетов, в котором участвовала и РСФСР, приняв 12.06.1990 Декларацию о суверенитете; введение поста Президента СССР и РСФСР, когда 12.06.1991 был избран первым Президентом РСФСР - Б. Н. Ельцин; возврат к рыночной экономике, к капиталистическим отношениям. До распада СССР оставалось 5 месяцев. ... Но когда тебе 23 и вся жизнь впереди, то помыслы совершенно иные.

Какими видами спорта Миша интересовался? Спорт любил, практически всё перепробовал. Остановился на лёгкой атлетике (особенно нравилось многоборье). После 4го класса регулярно посещал курсы спасателей (тогда это у нас называлось пожарной командой). Стал подрастать и только твердил, что о горах. Увлекся альпинизмом.

М. Майборода получил назначение на таджикско-афганскую границу и через год 01.09.1992 Майборода был назначен начальником 12-ой пограничной заставы Московского пограничного отряда группы пограничных войск РФ в 
Республике Таджикистан, который расположился недалеко от кишлака Саригор Шурабадского района, Хатлонской обл., Республики Таджикистан [2].

Российским пограничникам пришлось нести службу в условиях военной обстановки. С одной стороны бесчисленные преобразования в экономической и военной сфере, реорганизация в органах безопасности, с другой - боевая обстановка в регионе. В начале 1993 г. в адрес пограничников со стороны афганских боевиков и формирований таджикской оппозиции чаще раздавались требования не препятствовать проходу через границу боевых и террористических групп и участились нападения на пограничные посты [3].

Во вторник 13 июля 1993 года около 4-х часов утра пограничный наряд сообщает на 12-ю заставу, что со стороны Афганистана в темноте движется группа вооруженных людей. Начальник заставы ст. лейтенант Майборода поднял по тревоге весь личный состав. Боевики поняли, что их обнаружили и начали штурм, используя более 25 единиц различных видов орудий [4].

Весь личный состав в количестве 48-ми пограничников занял оборону в окопах и открыл ответный огонь по врагу. В первые же минуты боя начальник заставы Майборода организовал оборону заставы - поставил конкретные задачи сержантам и направился руководить обороной заставы на наиболее напряженный участок, со стороны границы.

Каким Миша был в детстве? Иной раз приходил домой весь побитый постоянно заступался за всех младших и за друзей. Очень любил друзей, ради них жизнь отдать было для него делом чести. Однажды я у него спросила, что случилось. Рассказал, что за всю компанию заступался, дрался один, а остальные стояли в стороне: одному аппендицит только вырезали, у остальных тоже нашлись свои причины. Я спросила: «А вот если бы тебе вырезали аппендицит?». Ответил: «Я бы не стоял!»

Возле начальника валялись 4 пустых автоматных магазина. Несмотря на ранение, М.Майборода держался до последнего патрона [5]. Он погиб после того, как ему осколками были повреждены лёгкие, позвоночник. За 3 дня до 
этого боя 10 июля Михаилу исполнилось 25 лет. Командование заставой принял на себя заместитель начальника заставы Андрей Мерзликин. На заставе находился и родной брат Майбороды - Иван Викторович, который со всеми остальными бойцами с оружием в руках отбивал атаки нападавших боевиков [6].

«Застава вела бой до тех пор, пока не кончились патроны и гранаты вспоминал впоследствии Андрей Мерзликин. После того, как стало ясно, что в ближайшее время помощи ждать неоткуда, а тем, кто останется на заставе грозит неминуемая гибель, я принял решение прорываться. В минуту недолгого затишья я собрал всех оставшихся в живых бойцов, рассказал о своем решении прорываться. Несколько человек, которым было трудно передвигаться самостоятельно, добровольно предложили прикрыть наш отход...» [7]. В 14 часов 20 минут группа пограничников сквозь окружение начала прорыв.

По словам начальника Московского пограничного отряда подполковника Василия Масюка: «В пяти километрах от расположения 12-й заставы нам навстречу вышла группа пограничников во главе с лейтенантом Андреем Мерзликиным. Он с трудом выговаривал слова: - «Товарищ подполковник, личный состав 12-ой заставы, оставшийся в живых, находится перед вами. Заместитель начальника заставы лейтенант Мерзликин», - этот короткий доклад срывающимся от контузии голосом, дошедший до нас благодаря уникальным кадрам кинохроники Дмитрия Коняхина, никого не оставил равнодушным [8].

Строй из 19-ти окровавленных, едва не падающих от смертельной усталости солдат... Им с трудом верилось, что они уже у своих, что весь кромешный ад, через который им пришлось пройти, уже позади. Вскоре был вызван вертолет, и в 17.00 вышедшие из боя люди были эвакуированы...» [9].

Указом Президента РФ от 19 июля 1993 года за мужество и отвагу, проявленные при исполнении воинского долга 13 июля 1993 года [10], орденами и медалями были награждены воины Московского пограничного отряда [11].

Старший лейтенант Михаил Викторович Майборода был посмертно награжден орденом «За личное мужество». Захоронен по месту рождения - в 
городе Алма-Ата в Казахстане [12].

Родные Михаила Викторовича Майбороды, переехали из Казахстана в Россию. Орден «За личное мужество» украли при ограблении квартиры родителей в Алма-Ате. Деньги, перечисленные родителям Михаила по случаю гибели сына и продажи алма-атинской квартиры, пропали в период денежной реформы 1998 года. Как и миллионы бывших советских граждан они оказались втянутыми в многочисленные политические и экономические реформы, осуществлявшимися в период смены государственной власти. В России приютил родителей Майбороды боевой товарищ Михаила - Андрей Мерзликин [13]. Жили они в доме его отца в селе Демкино Липецкой области. И только благодаря широкой компании Владимира Шальнёва, однокурсника Михаила по Голицынскому училищу со своими друзьями - ветеранами пограничных войск и органов безопасности 28 мая 2010 года родители, братья Иван и Илья получили

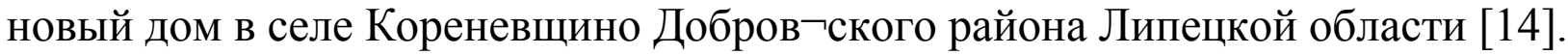

Сегодня, спустя 23 года, действиям начальника заставы, подвигу пограничной заставы даются различные характеристики. Конечно, легче всего оценивать события со стороны: указать на ошибки, недочёты, недоработки командования. Да, после июльского боя были приняты различные меры. Отправили в отставку командующего Пограничными войсками РФ, министру безопасности РФ объявили выговор за выявленные недостатки в работе. Разрушенную заставу восстановили перенеся её выше в горы и приказом министра безопасности РФ от 01.11.1993 12-я пограничная застава получила имя «Пограничная застава имени 25 героев». 12.07.2005 по приказу директора ФПС В. Е. Проничева Московский пограничный отряд был расформирован [15].

Это событие - трагический пример того, что происходит с обществом в период смены формы правления, государственного устройства и государственного режима. Когда всё общество оказалось на перекрёстке выбора. И суть боя 13 июля 1993 года в том, что ребята из разных уголков бывшей советской державы, оказавшиеся по контракту или военному призыву здесь, на 
окраине уже не существующей страны, сплотившись в единое целое выполнили свой не только воинский, но самое главное человеческий долг. Они убедительно доказали, что есть люди, для которых «родина» и «честь» не простые слова. И даже в эпоху перемен человек должен оставаться...

- Имеем честь обратится к Вам Иван Викторович. Ваши слова очень важны для нас. Как Вы 19-летний новобранец прошли июльский ад 1993 года и остались Человеком.

- Если ты человек, то никакого ада нет. Просто есть в жизни разные ситуации. И даже в эпоху перемен человек должен оставаться... человеком. 


\section{Литература:}

1. История в фотографиях. 20 лет назад. 12-я застава Московского пограничного отряда. [Электронный ресурс]. - Режим доступа: http://fotohistory.livejournal.com/3771221.html

2. Захарчев Н. Правда о знаменитом Пянджском сражении в воспоминаниях очевидиев / Аргументы и факты. [Электронный ресурс]. http://www.ul.aif.ru/persona/details/165183 (дата обращения: 26.09.2015). 12 погранзастава. [Электронный ресурс]. - Режим доступа: http://vk.com/club33637669 (дата обращения: 26.09.2015).

3. Алексей Кондратенко. Застава имени 25 героев. Учительская газета. - 15 июля 2003 года. - № 29. [Электронный ресурс]. - Режим доступа: http://www.ug.ru/archive/993 (дата обращения: 20.09.2015). Двенадцатая застава: июль 1993- го. Документальный фильм. Режиссёр Л. Верещагина. 2008 .

4. Николай Иванов. Бойцы 12-й погранзаставы не пропустили Хаттаба в Таджсикистан: 10 лет назад постсоветская Россия отбила первый натиск международного терроризма. 11 июля 2003 г. [Электронный ресурс]. Режим docmyna: http://www.russian.kiev.ua/archives/2003/0307/030713tpt1.shtml (даma обращения: 20.09.2015).

5. Виктор Летов. 12-я застава, 10 лет спустя. 13 июля 1993 года пограничники заставы “Соригор” приняли неравный бой... [Электронный ресурс]. - Режсим доступа: http://greenzone3000.narod.ru/pressa/sorigor10let/ sorigor10let5.htm (дата обращения: 26.09.2015).

6. Сулимов Игорь. Застава принимает бой / Военное обозрение. [Электронный ресурс]. - Режим доступа: http://topwar.ru/29384-zastavaprinimaet-boy.html (дата обращения: 26.09.2015). Иван Майборода: «Бой шел 11 часов. За это время мы потеряли половину погранзаставы» 
[Электронный pесурс]. - Режим достуnа: http://sokolskymg.livejournal.com/42329.html (дата обращения: 26.09.2015).

7. Военное обозрение. 13 июля 1993 года... [Электронный ресурс]. - Режим достуna: http://topwar.ru/30798-13-iyulya-1993-goda.html (дата обращения: 20.09.2015).

8. Олег Грозный, В. Петров. Огненная застава. 22 года назад пограничники Московского погранотряда в Таджикистане остановили боевиков / Красная звезда. - 12 июля 2015 года. «Огненная застава. Оставшиеся 6 живых». 2013 - документальный фильм режиссёра Игоря Чернова, сиенарий Сладкова Александра Валерьевича, Коняхина Дмитрия Александровича.

9. Алексей Кондратенко. - Указ. Соч.

10. Указ Президента РФ от 19 июля 1993 г. № 1050 "О присвоении звания Героя Российской Федерации военнослужащим Пограничных войск Российской Федерации" // Собрание актов Президента и Правительства Российской Федерации от 26 июля 1993 г., № 30, ст. 2780

11. Пограничная застава имени 25 героев. [Электронный ресурс]. - Режим достуna: http://pogranec.ru/showthread.php?t=3532 (дата обращения: 16.09.2015).

12. Знаете, каким он парнем был? Михаил Майборода // Граница России. 2000. - № 42.

13. Военно-исторический вестник. 12-я Погранзастава Московского пограничного отряда. 29.05.2010. [Электронный ресурс]. - Режим docmyna: $\quad$ http://tankiwar.ru/vooruzhennye-konflikty/12-ya-pogranzastavamoskovskogo-pogranichnogo-otryada (дата обращения: 19.09.2015).

14. Старцева А. Неизвестная война. Не гоже так с героями... Родители Михаила Майбородьл. [Электронный ресурс]. - Режим доступа: http://neizv-vojna.livejournal.com/2801.html (дата обращения: 03.10.2015). Илья и Ольга Майборода: пограничная любовь. [Электронньй ресурс]. - 
Режим доступа: http://ntsk.ru/?r=news/article\&id=420 (дата обращения: 03.10.2015). Кавджарадзе М. Г. В День пограничника семье Героя вручили ключи от дома. 29.05.2010. [Электронный ресурс]. - Режим доступа: http://kavdjaradze.ru/news/main/1169 (дата обращзения: 17.09.2015). Грозный О., Петров В. Огненная застава: 22 года назад пограничники Московского погранотряда в Таджикистане остановили боевиков [Электронный ресурс]. - Режим доступа: http://www.redstar.ru/index.php/news-menu/varmiyakh-sng/tadzhikistan/item /24855-ognennaya-zastava (дата обращения: 26.09.2015). Дом для героя-пограничника. 28.05.2010. [Электронный ресурс]. - Режим доступа: http://old.lipetsktime.ru /news/2010-0528/5091.htm (дата обращения: 17.09.2015).

15. 117-му Московскому пограничному отряду, в - ч 2033 - 80 лет! [Электронный pecypc]. - Режим доступа: http://rsva59.ru/home/moskovskomu_po_80let.html_ (дата обращения: 23.09.2015). 117 Московский погранотряд, в/ч 2033. [Электронный ресурс]. - Режим доступа: http://pv-afghan.narod.ru/militant_action_table/ 117_Moscowsky.htm (дата обращения: 23.09.2015). Новости Таджикистана. 12 погранзастава - застава героев. Назриев Д., Саттаров И. Республика Таджикистан: история независимости (хроника событий). Год 1993-й. Июль. [Электронный $\quad$ ресурс]. - Режим доступа: http://www.toptj.com/m/news/2014/05/23/12 pogranzastava_zastavageroev (дата обращения: 23.09.2015). 